\title{
Ripening of "Pedro Sato" guava: study on its climacteric or non-climacteric nature
}

\author{
Marisa Azzolini' ${ }^{1}$, Angelo Pedro Jacomino²*, Ilana Urbano Bron ${ }^{3}$, Ricardo Alfredo Kluge ${ }^{4}$ and Marlene \\ Aparecida Schiavinato 5
}

\begin{abstract}
${ }^{1}$ Departamento de Botânica, Universidade Federal do Rio Grande do Sul, 91501-970, Porto Alegre, RS, Brasil; ${ }^{2}$ Departamento de Produção Vegetal, Escola Superior de Agricultura Luiz de Queiroz, Universidade de São Paulo, CP 9, 13418-900, Piracicaba, SP, Brasil; ${ }^{3}$ Centro Apta de Engenharia e Automação, Instituto Agronômico de Campinas, CP 26, 13201-970, Jundiai, SP, Brasil; ${ }^{4}$ Departamento de Ciências Biológicas, Escola Superior de Agricultura Luiz de Queiroz, Universidade de São Paulo, CP 9, 13418-900, Piracicaba, SP, Brasil; ${ }^{5}$ Departamento de Fisiologia Vegetal, Instituto de Biologia, Universidade Estadual de Campinas, CP 6109, 13083-862, Campinas, SP, Brasil; *Corresponding author: jacomino@esalq.usp.br.

Received: 17/06/2005, Accepted: 03/10/2005
\end{abstract}

Guava (Psidium guajava L.) is a tropical fruit exhibiting rapid post-harvest ripening. However, the physiological basis involved in the ripening process of guava is not totally clear, which makes it difficult to develop technologies to enhance fruit storability. Two experiments were carried out with the objective of determining the ripening behavior of 'Pedro Sato' guavas. In the first experiment, guava fruits at three maturity stages (I - dark green, II - light green and III - yellow-green) were stored at room temperature $\left(23 \pm 1^{\circ} \mathrm{C}\right.$ and $\left.85 \pm 5 \% \mathrm{RH}\right)$. The respiratory rate, ethylene production, pulp and skin colours, and firmness were evaluated. In the second experiment, ethylene and 1-methylcyclopropene (1-MCP) were applied to guavas at the light green maturity stage and the ripening behaviour during storage at room temperature was studied. Fruits from all maturity stages showed a gradual increase in the respiratory rate and ethylene production. The intense changes in pulp and skin colours and in firmness preceded the maximum respiratory rate and ethylene production. 1-MCP reduced the rate of ripening, while the application of ethylene did not promote this process. These results do not permit the classification of 'Pedro Sato' guava as a traditional climacteric fruit.

Keywords: Psidium guajava, ethylene, 1-methylcyclopropene, respiration.

Amadurecimento de goiabas 'Pedro Sato': estudo sobre sua natureza climatérica ou não climatérica: A goiaba (Psidium guajava L.) é um fruto tropical que apresenta rápido amadurecimento após a colheita. Entretanto, as bases fisiológicas envolvidas no seu processo de amadurecimento ainda não estão totalmente claras, o que torna difícil o desenvolvimento de técnicas que prolonguem o armazenamento. Realizaram-se dois experimentos com o objetivo de determinar o comportamento do amadurecimento de goiabas 'Pedro Sato'. No primeiro, goiabas em três estádios de maturação (I - verde-escuro, II - verdeclaro e III - verde-amarelado) foram armazenadas à temperatura ambiente $\left(23 \pm 1^{\circ} \mathrm{C}\right.$ e $\left.85 \pm 5 \% \mathrm{UR}\right)$, avaliando-se taxa respiratória, a produção de etileno, a cor da casca e da polpa e a firmeza. No segundo experimento, aplicaram-se etileno e 1-metilciclopropeno (1-MCP) nas goiabas no estádio verde-claro e estudou-se o comportamento do amadurecimento durante armazenamento à temperatura ambiente. Frutos de todos os estádios de maturação mostraram aumento gradual na taxa respiratória e produção do etileno. As mudanças intensas na cor da casca e da polpa e da firmeza precederam a máxima taxa respiratória e produção de etileno. 1-MCP retardou o amadurecimento, enquanto a aplicação de etileno não promoveu esse processo. Tais resultados não permitem a classificação da goiaba 'Pedro Sato' como um tradicional fruto climatérico.

Palavras-chave: Psidium guajava, etileno, 1-metilciclopropeno, respiração. 


\section{INTRODUCTION}

Brazil is the main world producer of guava. One of the most cultivated guavas in this country is the red pulp cultivar 'Pedro Sato', the most preferred in the national market. Guava is considered one of the most balanced fruits, having high a content of vitamin A, ascorbic acid and lycopene, widely studied for its medical properties (Sharma, 1999). Guava is characterized as a highly perishable fruit, which completes its ripening process in a few days after harvest when kept at ambient temperature. Guava harvested at the green maturity stage and stored at room temperature has a maximum shelf life of six days, while at a more advanced stage of ripening, shelf life is reduced to two days (Bleinroth, 1996).

Traditionally, according to the respiratory pattern, fruits have been classified as climacteric or non-climacteric (Biale, 1964). Climacteric fruits are those whose ripening is accompanied by a distinct increase in respiratory rate, which is generally associated with elevated ethylene production just before the increase in respiration. After the climacteric rise, ethylene production declines significantly during the postclimacteric phase (Hoffman and Yang, 1980). In these fruits, ethylene plays a key role in the physiological and biochemical changes that occur during ripening (Lelièvre et al., 1997; Giovannoni, 2001). On the other hand, nonclimacteric fruits are those that do not exhibit increases in ethylene and respiration, but rather undergo a gradual decline in respiration during ripening (Knee et al., 1977).

Climacteric fruits present different ripening phases. Before the onset of ripening, preclimacteric fruits produce low levels of ethylene (system 1). At the onset of the climacterium, there is a high rate of ethylene production (system 2) and its regulation becomes autocatalytic (McMurchie et al., 1972).

Studies involving treatments with exogenous ethylene have indicated that the fruit response may also serve to distinguish between climacteric and non-climacteric fruits (McMurchie et al., 1972). In typical climacteric patterns of ripening, the application of ethylene advance and enhance the onset of respiration and ethylene climacterics, while in non-climacteric fruits, exogenous ethylene application just leads to a transitory respiration response (Bufler, 1986). According to Ludford (2003), the main difference between climacteric and non-climacteric fruits lies in their autocatalytic production of ethylene in response to threshold levels of ethylene. Atta-Aly et al. (2000) suggested that a negative ethylene feedback mechanism could underlie the non-climacteric behavior, while a positive feedback mechanism underlies climacteric behavior during ripening.

The classification of guava as a climacteric or nonclimacteric fruit is contradictory. Many authors consider guava as a non-climacteric fruit (Biale and Barcus, 1970; Medina et al., 1988; Chitarra and Chitarra, 1990), while others consider it to be a climacteric fruit (Akamine and Goo, 1979; Brown and Wills, 1983, and Mercado-Silva et al., 1998). According to Botelho (1996), this is a varietal characteristic. With regard to 'Pedro Sato' guava, contradictory reports as to the ripening pattern have also been observed. Mattiuz (2002) demonstrated that 'Pedro Sato' guava presented a constant increase in respiratory rate up to seven days after harvest, when the fruit was already senescent.

The objective of this work was to study the ripening process of 'Pedro Sato' guava harvested at different maturity stages, and verify the effects of ethylene and 1-methylcyclopropene on the ripening of this cultivar.

\section{MATERIAL AND METHODS}

Plant material: 'Pedro Sato' guava fruits were harvested from a commercial orchard in the Vista Alegre district of São Paulo State, and transported by a refrigerated vehicle at $15^{\circ} \mathrm{C}$ during a $4 \mathrm{~h}$ journey to Piracicaba, São Paulo State. The fruits were selected according to their weight $(150 \pm 10 \mathrm{~g})$ and classified with the aid of a Minolta CR-300 colorimeter, for one of the three maturity stages: stage 1 (dark green) $=$ hue angle $\left(\mathrm{H}^{\circ}\right)$ between $120^{\circ}$ and $117^{\circ}$; stage 2 (light green) $=\mathrm{H}^{\circ}$ between $116^{\circ}$ and $113^{\circ}$; stage 3 (yellow-green) $=\mathrm{H}^{\circ}$ between $112^{\circ}$ and $108^{\circ}$.

Fruits were treated with the fungicide Prochloraz $(0,250$ mg. $\mathrm{L}^{-1}$ ) for three minutes. This treatment was carried out to avoid rot incidence, which could influence the respiration and ethylene production during ripening. Fruits were placed in cardboard boxes and stored at $23 \pm 1^{\circ} \mathrm{C}$ and $85 \pm 5 \% \mathrm{RH}$.

Assessments: The ripening assessments for guava (skin and pulp colour, and firmness) were evaluated every two days up to 12 days after harvest. Skin and pulp colours were determined using a Minolta CR-300 colorimeter and results expressed as hue angle $\left(\mathrm{H}^{\circ}\right)$ for skin colour and as Chroma (C) for pulp colour. Skin colour was evaluated by means of two readings on opposite sides along the fruit's equatorial region, while pulp colour was evaluated by a single reading in the middle of the fruit's placental region after transversal cutting. Pulp firmness, expressed in Newtons $(\mathrm{N})$, was 
determined with an 8-mm point digital penetrometer, by carrying out two readings per fruit on opposite sides along the fruit's equatorial region.

Respiratory rate and ethylene production: The respiratory rate and ethylene production were evaluated every 12 or 24 h, using 10 replicates. Fruits with known masses were individually placed in $590 \mathrm{~mL}$ hermetically sealed flasks for one hour. The $\mathrm{CO}_{2}$ concentration in the flasks was determined by means of a Check Mate PBI Dansensor gas analyzer. Results were expressed as $\mathrm{mL} \mathrm{CO} \cdot \mathrm{kg}^{-1} \cdot \mathrm{h}^{-1}$. Ethylene was evaluated by means of a gas chromatograph (Shimadzu GC-14B, Japan) and results were expressed as $\mu \mathrm{L} \mathrm{C}_{2} \mathrm{H}_{4} \cdot \mathrm{kg}^{-1} \cdot \mathrm{h}^{-1}$.

Applications of ethylene and 1-methylcyclopropene (1$M C P)$ : Guava fruits at stage 2 were treated with ethylene or 1-MCP in the following manner. Fruits were treated with Azetil $^{\circledR}$ (containing 5.0\% ethylene at a concentration of 1,000 $\left.\mu \mathrm{L} . \mathrm{L}^{-1}\right)$. Fruits were placed in hermetically sealed chambers $\left(0.19 \mathrm{~m}^{3}\right)$ and exposed to ethylene for $24 \mathrm{~h}$ at $23^{\circ} \mathrm{C}$. After treatment, the chambers were opened and the fruits were kept under room conditions $\left(23 \pm 1^{\circ} \mathrm{C}\right.$ and $\left.85 \pm 5 \% \mathrm{RH}\right)$. For the treatment with 1-MCP, fruits were treated with SmartFresh ${ }^{\mathrm{TM}}$ wetable powder, containing $0.14 \% 1-\mathrm{MCP}$ active ingredient, at a concentration of 300 nL.L-1 . Fruits were placed in hermetically sealed chambers and exposed to the product for $12 \mathrm{~h}$ at $23^{\circ} \mathrm{C}$. In order to obtain the required 1-MCP concentration inside the chambers, predetermined amounts of SmartFresh ${ }^{\mathrm{TM}}$ were transferred to capped flasks. Distilled water $(20 \mathrm{~mL})$ at $50^{\circ} \mathrm{C}$ was added to the flasks and stirred until complete dissolution of the product. Then, the flasks were opened inside the chambers, which were immediately sealed to avoid gas loss. After treatment, the chambers were opened and fruits kept under room conditions.

Data analysis: Analyses were performed using a completely randomized design, with ten replicates for each day of analyses ( $\mathrm{n}=10$ fruits). The data were subjected to analysis of variance and the least significant differences (LSD) calculated.

\section{RESULTS}

Fruits at the three maturity stages showed a constant increase in the respiratory rate during storage at room temperature (figure 1A). The minimum respiratory rates observed were 29,40 and $39 \mathrm{~mL} \mathrm{CO} \mathrm{kg}^{-1} \cdot \mathrm{h}^{-1}$ for stages 1,2 and 3, respectively. Respiration was fairly stable up to 4 days after harvest, when it began to raise reaching values of $85 \mathrm{~mL}$ $\mathrm{CO}_{2} \mathrm{~kg}^{-1} \cdot \mathrm{h}^{-1}$ for stages 1 and 2 and $74 \mathrm{~mL} \mathrm{CO}_{2} \mathrm{~kg}^{-1} \cdot \mathrm{h}^{-1}$ for stage 3 . These maximum respiratory activities were observed on the $8^{\text {th }}, 10^{\text {th }}$ and $12^{\text {th }}$ days after harvest for fruits at stages 3, 2 and 1, respectively (figure 1A).

Ethylene production varied similarly to the respiratory rate (figure 1B). Fruits at stages 1, 2 and 3 produced 0.42 , 1.44 and $1.51 \mu \mathrm{L}$ ethylene $\mathrm{kg}^{-1} \cdot \mathrm{h}^{-1}$, respectively, 12 hours after harvest. The highest values for ethylene production were observed at nine days after harvest for stages 1 and 2 (3.25 and $3.70 \mu \mathrm{L} \mathrm{kg}^{-1} \cdot \mathrm{h}^{-1}$, respectively), and eight days after harvest for stage $3\left(3.70 \mu \mathrm{L} \mathrm{kg}^{-1} \cdot \mathrm{h}^{-1}\right)$ (figure 1B).

The reduction in the skin colour $\left(\mathrm{H}^{\circ}\right)$ represents a change from green to yellow. Fruits harvested at stage 1 were always greener than those at the other stages during storage (figure 2). Stage-1 fruits showed two periods of intense change in skin colour, one between the $2^{\text {nd }}$ and $4^{\text {th }}$ days after harvest (42\% of total $\mathrm{H}^{\mathrm{o}}$ variation) and another between the $10^{\text {th }}$ and $12^{\text {th }}$ days after harvest ( $45 \%$ of total $\mathrm{H}^{\circ}$ variation). The

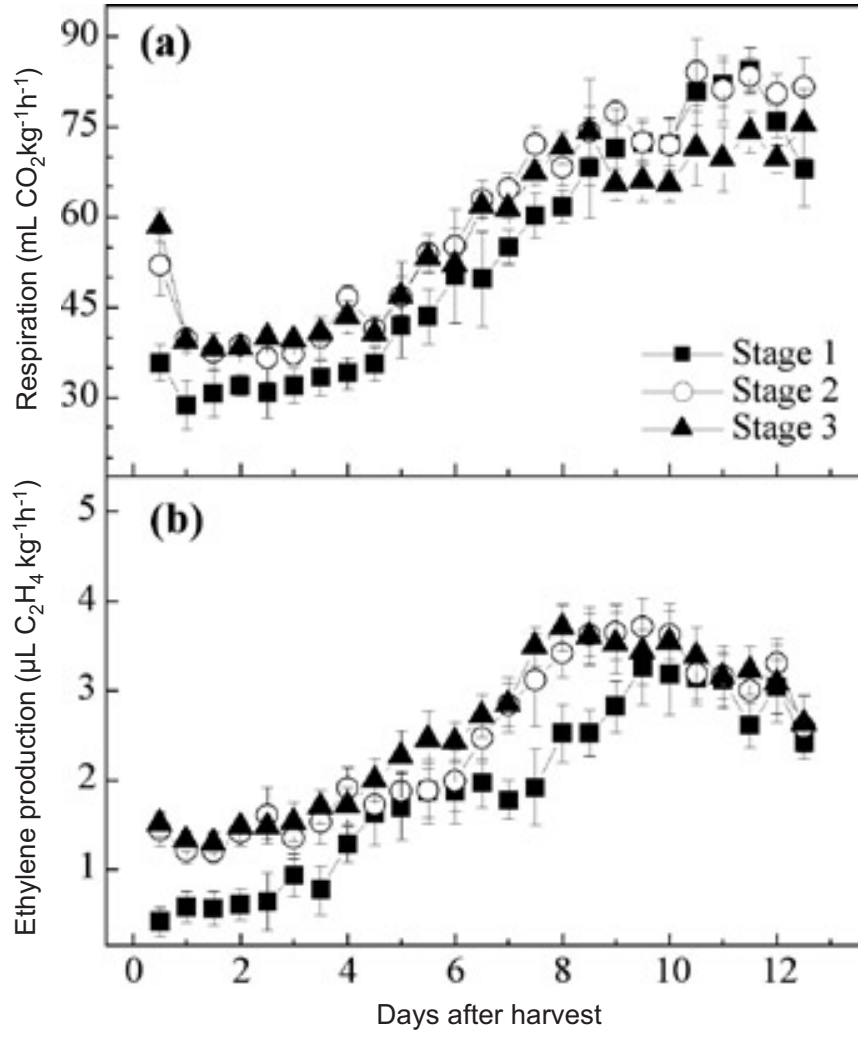

Figure 1. Respiratory rate (a) and ethylene production (b) of 'Pedro Sato' guavas harvested at different maturity stages and stored at room temperature $\left(23^{\circ} \mathrm{C}\right.$ and $\left.85 \% \mathrm{RH}\right)$. Stage 1 = dark green; stage 2 = light green; stage 3 =yellow-green. Vertical bars represent $\pm \operatorname{SD}(n=10)$. 
most intense skin colour change occurred between the $2^{\text {nd }}$ and $4^{\text {th }}$ days after harvest for stages 2 and 3 . In both cases, the intense changes in skin colours occurred before maximum ethylene production (figure 2).

With regard to pulp colour, there was an increase in Chroma (C) up to ten days after harvest for all maturity stages, indicating the development of a more intense pulp colour (figure 3). After this increase, there was a reduction in $\mathrm{C}$ values, probably due to the destruction of pigments as a function of fruit senescence ten days after harvest. Apparently, ethylene production did not have a strong influence on this ripening characteristic (figure 3).

Fruits at all maturity stages showed intense loss of firmness, as well as a gradual increase in ethylene production

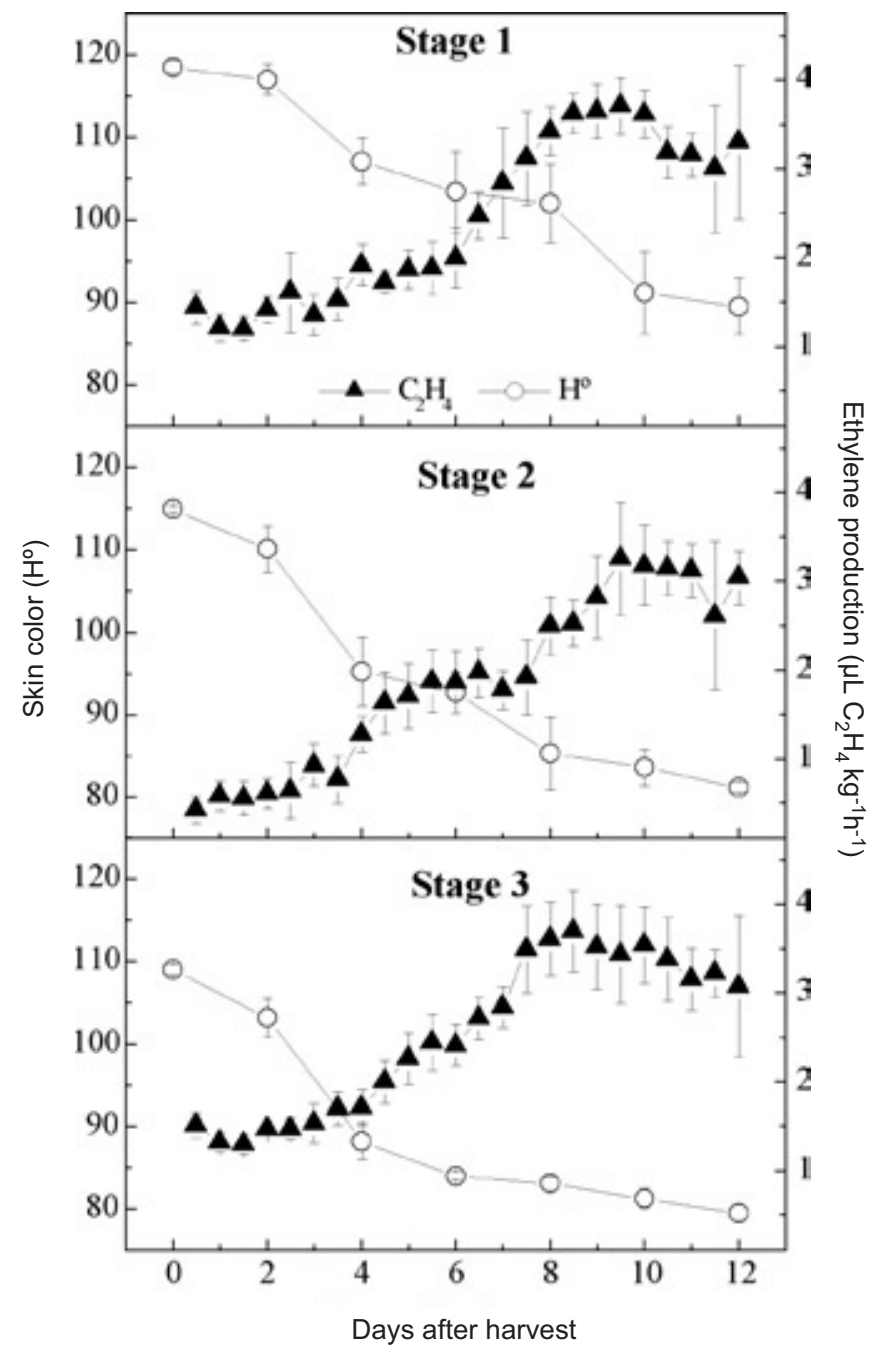

Figure 2. Changes in ethylene production and in skin colour of 'Pedro Sato' guavas harvested at different maturity stages and stored at room temperature $\left(23^{\circ} \mathrm{C}\right.$ and $\left.85 \% \mathrm{RH}\right)$. Stage $1=$ dark green; stage $2=$ light green; stage $3=$ yellow-green . Vertical bars represent $\pm \operatorname{SD}(n=10)$. (figure 4). However, when fruits were producing the highest amounts of ethylene, the decrease in firmness had already stabilized.

Fruits harvested at stages 3, 2 and 1 developed off-flavour two, four and six days after harvest, respectively. In addition, during these periods fruits became much softer and presented a "gummy" aspect (Reyes and Paull, 1995) in the placental region (data not shown).

Fruits harvested at stage 2 and treated with 1-MCP exhibited a low respiratory rate and ethylene production comparable to both non-treated and ethylene-treated fruits. The respiratory rate and ethylene production verified in ethylene- treated fruits were similar to those observed in control fruits (figures 5A and 5B). Although 1- MCP reduced

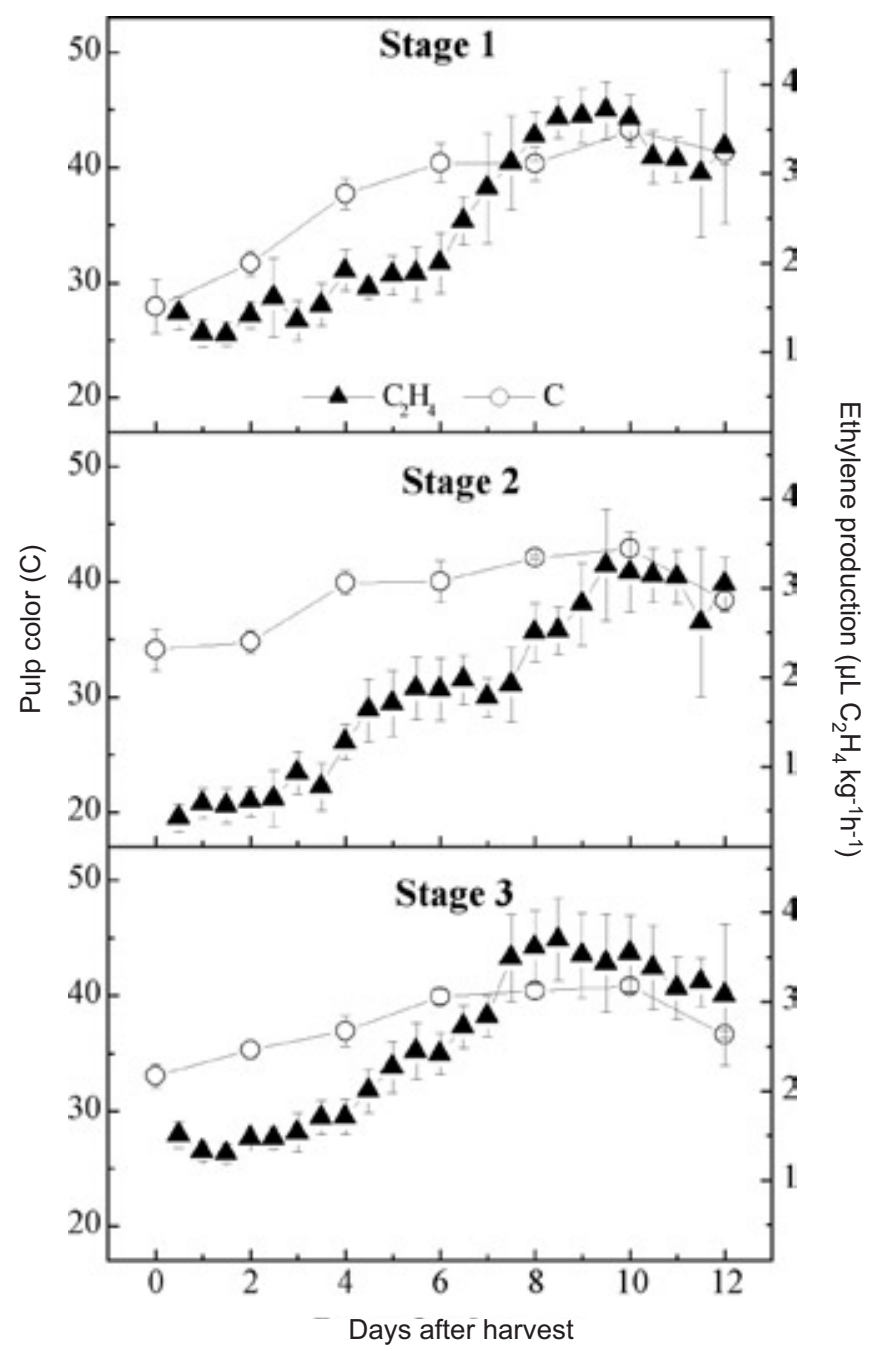

Figure 3. Changes in ethylene production and in pulp colour of 'Pedro Sato' guavas harvested at different maturity stages and stored at room temperature $\left(23^{\circ} \mathrm{C}\right.$ and $\left.85 \% \mathrm{RH}\right)$. Stage 1 = dark green; stage 2 = light green; stage 3 = yellow-green . Vertical bars represent $\pm \operatorname{SD}(n=10)$. 
respiration, the maximum respiratory rate occurred within the same period as for the other treatments. Exogenous application of ethylene did not result in an increase in endogenous production of this hormone (figure 5B), in contrast to that observed for many climacteric fruits.

1-MCP affected fruit firmness and changes in skin and pulp colours, while ethylene did not alter these ripening characteristics (figure 6). Loss of firmness was significantly reduced in fruits treated with 1-MCP (figure 6A). Skin colour remained green in fruits treated with $1-\mathrm{MCP}$ up to the $12^{\text {th }}$ day, while non-treated or ethylene-treated fruits exhibited a totally yellow skin six days after harvest (figure 6B). Pulp colour showed increasing values up to nine days after harvest in both non-treated and ethylene-treated fruits (figure 6C).

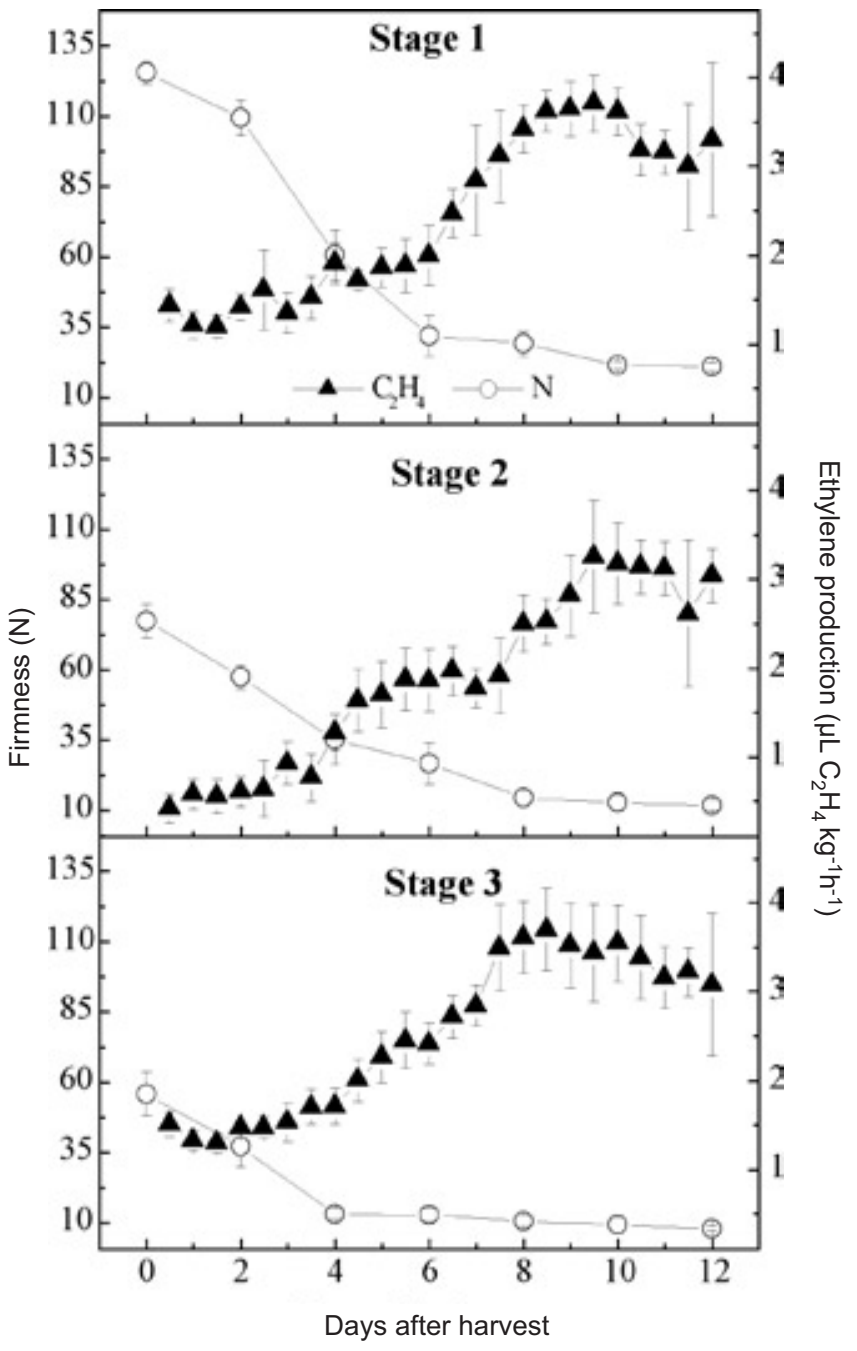

Figure 4. Changes in ethylene production and in firmness of 'Pedro Sato' guavas harvested at different maturity stages and stored at room temperature $\left(23^{\circ} \mathrm{C}\right.$ and $85 \%$ $\mathrm{RH})$. Stage $1=$ dark green; stage $2=$ light green; stage 3 $=$ yellow-green. Vertical bars represent $\pm \operatorname{SD}(n=10)$.
Fruits treated with 1-MCP showed less intense pulp colour than fruits from the other treatments only up to six days after harvest.

\section{DISCUSSION}

As occurs with climacteric fruits, guavas harvested at all maturity stages complete the ripening processes after harvest, showing profound changes in some attributes such as skin colour and firmness. However they did not present typical climacteric respiratory activity. In fact, a gradual increase in the respiratory rate was observed reaching maximum rates when guavas were already ripe (figures 1, 2 and 4). Bron et al. (2005) also observed a gradual increase in respiration in 'Paluma' guavas, harvested at maturity stage 2 (light-green skin) and stored at $25^{\circ} \mathrm{C}$. By definition, climacteric fruits are those that show a significant increase in respiration during ripening (Rhodes, 1980; Yang, 1985; Lelièvre et al., 1997). In typical climacteric fruit, before the onset of ripening, a low respiratory activity is observed, while at the climacterium, there is a surge in respiratory activity (Oetiker and Yang, 1995), followed by changes in quality attributes. In spite

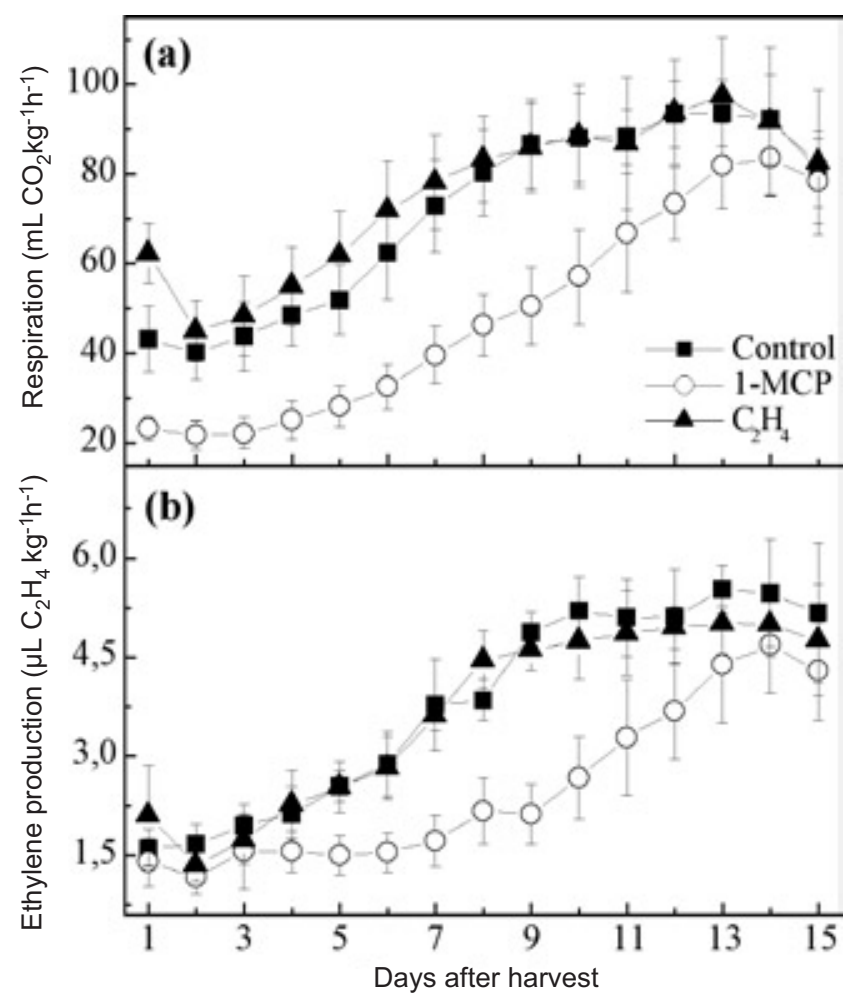

Figure 5. Respiratory rate (a) and ethylene production (b) of 'Pedro Sato' guavas treated or not with ethylene $\left(1,000 \mu \mathrm{L} . \mathrm{L}^{-1}\right)$ or $1-\mathrm{MCP}\left(300 \mathrm{~nL} . \mathrm{L}^{-1}\right)$ and stored at room temperature $\left(23^{\circ} \mathrm{C}\right.$ and $\left.85 \% \mathrm{RH}\right)$. Vertical bars represent $\pm \mathrm{SD}(\mathrm{n}=10)$. 
of the suggestion by some authors (Brown and Wills, 1983, Mercado-Silva et al., 1998) that guava is a climacteric fruit, according to our data on respiratory behavior, 'Pedro Sato' guavas can not be classified as a traditional climacteric fruit. This is in agreement with other authors (Biale and Barcus, 1970; Medina et al., 1988; Chitarra and Chitarra, 1990). It is possible that this is really a varietal characteristic, as shown by Botelho (1996). Indeed, the respiratory rate observed for 'Pedro Sato' guavas was higher than that observed for the 'Kumagai' cultivar (Oliveira and Cereda, 1999).

The increase in respiration rates during ripening of climacteric fruits is considered to be a homeostatic response of the mitochondria as an attempt to repair cell damage caused by the autocatalytic production of ethylene (Romani, 1984). The decrease in the respiration rates during post-climacteric represents the loss of homeostatic ability of mitochondria, with the predominance of senescence during this period. In this study, 'Pedro Sato' guavas maintained high respiratory rates and ethylene production, even after complete ripening. This observation suggests that 'Pedro Sato' guavas have the ability to maintain cell homeostasis, which leads to an increase in respiration and ethylene synthesis.

In this study, the values of ethylene production were similar to those observed by Akamine and Goo (1979) for 'Beaumont', 'Yellow strawberry', 'White' and 'Strawberry' guavas. The lower ethylene production at stage 1 may be due to the lower sensitivity of these fruits to ethylene (Yang, 1985). Such lower sensitivity seems to be related to the number of receptors in fruit tissue. According to Yen at al. (1995), the number of receptors increases during fruit ripening, which enhances ethylene action and its autocatalytic production.

According to Biale and Young (1981), the onset of climacteric fruit ripening is reflected by a dramatic increase in ethylene production, and once ripening is initiated more ethylene is produced as part of ripening process. In 'Pedro Sato' guavas this behavior was not observed.

Complete ripening is thought to occur when the fruit reaches the best quality standards for consumption (Watada et al., 1984; Wills et al., 1998). Based on this concept, 'Pedro Sato' guavas harvested at stages 3, 2 and 1 reached complete ripening two, four and six days after harvest, respectively. However, complete ripening, as indicated by intense changes in skin colour and firmness, occurs before the maximum rates of respiration and ethylene production. These results indicate that the initial concentration of ethylene was sufficient to trigger the ripening process and to allow fruits to reach maximum quality standards for consumption.
Exogenous application of ethylene to 'Pedro Sato' guavas did not accelerate fruit ripening, as occurs in many climacteric fruits (figures 5 and 6). Ripening velocity under such conditions was similar to that observed in control fruits. These results are in agreement with Reyes and Paull (1995) who found that ethylene treatment resulted in a rapid increase in skin yellowing of immature-green fruit but not on mature-green. The treatment of fruit with 1-MCP decreased the respiratory rate and ethylene production (figure 5). 1MCP binds to the ethylene receptor and acts as an ethylene antagonist (Sisler and Serek, 1997). Golding et al. (1998)

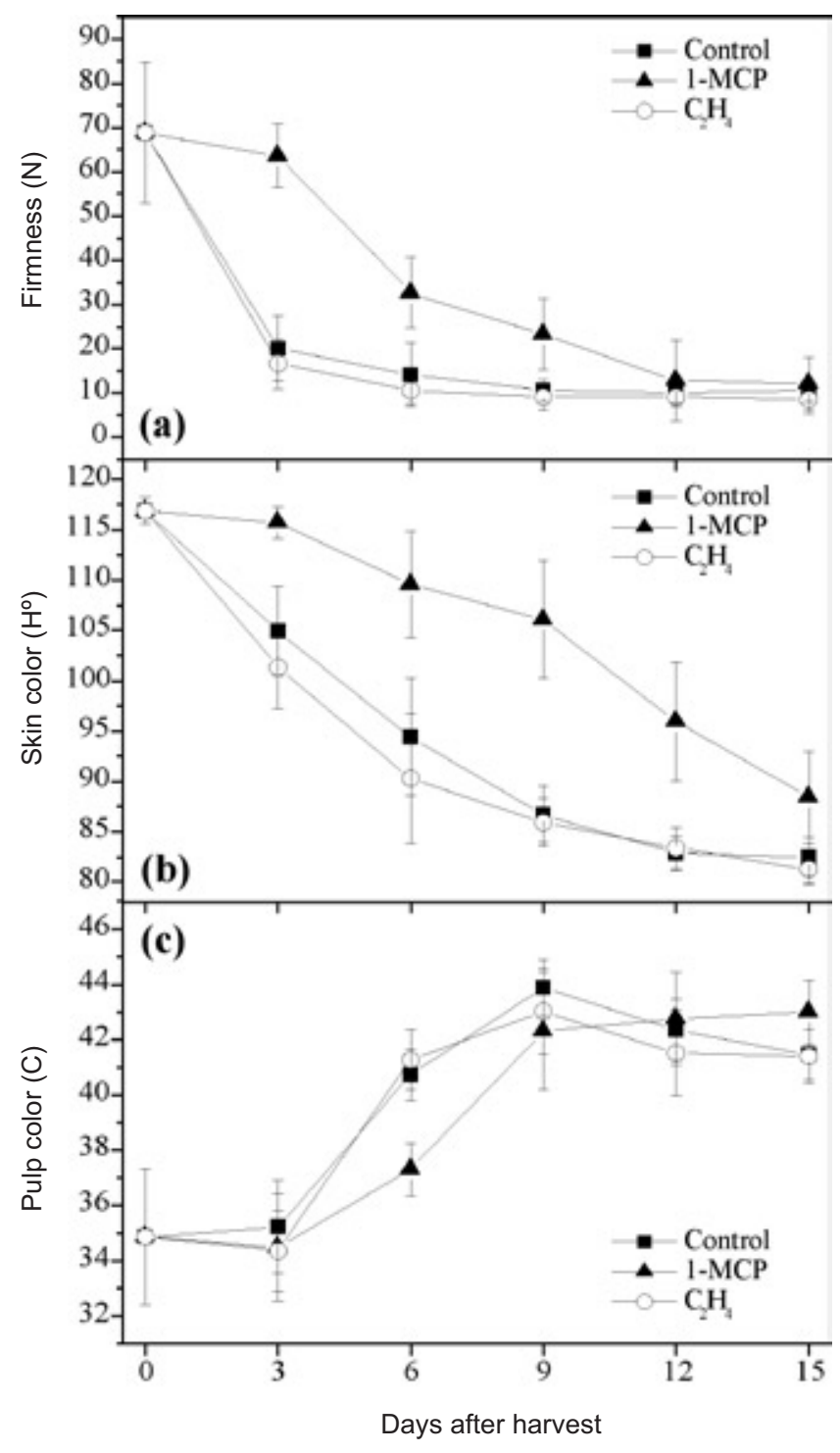

Figure 6. Firmness (a), skin colour (b) and pulp colour (c) of 'Pedro Sato' guavas treated or not with ethylene $\left(1,000 \mu \mathrm{L} . \mathrm{L}^{-1}\right)$ or 1 -MCP $\left(300 \mathrm{~nL} . \mathrm{L}^{-1}\right)$ and stored at room temperature $\left(23^{\circ} \mathrm{C}\right.$ and $\left.85 \% \mathrm{RH}\right)$. Vertical bars represent $\pm \mathrm{SD}(\mathrm{n}=10)$. 
demonstrated that the autocatalytic production of ethylene is reduced in fruits treated with 1-MCP, which may explain the lower ethylene production observed in 'Pedro Sato' guavas treated with 1-MCP. On the other hand, ripening in guavas was not totally blocked by $1-\mathrm{MCP}$, probably due to the synthesis of new ethylene receptors during ripening. This enables a reduced, but continuous, ethylene production, by the fruit (Yen et al., 1995). 1-MCP is known to delay ripening in several fruits, as reported by Blankenship and Dole (2003).

In spite of the intense changes in skin colour and firmness that occurred before maximum ethylene production, the development of these characteristics has been shown to be an ethylene-dependent phenomenon. This fact is evidenced by the retardation in green colour and firmness loss of the 1MCP-treated fruit (figure 6). The skin colour change depends on ethylene action, since it increases the expression of several enzymes involved in both the breakdown of chlorophyll and carotenoid biosynthesis (Wills et al., 1998).

The fruit softening verified during ripening is an important quality attribute, often determining shelf life. The main enzymes involved in the breakdown of the cell walls in guava have been reported as being pectinesterase, polygalacturonase and cellulase, among others (El-Zoghibi, 1994). Fruit softening is a ripening process considered to be highly sensitive to ethylene. In many fruits, the expression of pectinesterase and polygalacturonase appears to be dependent on ethylene action (Lelièvre et al., 1997). Gerasopoulos and Richardson (1996) demonstrated that the application of propylene, an analogue of ethylene, was capable of inducing fruit softening, although this treatment did not affect other ripening attributes. Thus, such high sensitivity to ethylene could explain the intense loss of firmness in 'Pedro Sato' guavas over the first days following harvest.

Fruits treated with 1-MCP showed slightly lower Chroma values than those found in both non-treated or ethylenetreated fruits up to six days after harvest (figure 6). The carotenoid lycopene is a very important component of the fruit as it is responsible for the red colour of the pulp (Cross, 1987). The biosynthesis of this pigment is strongly dependent on the presence of ethylene. In transgenic tomatoes with reduced ethylene production the synthesis of lycopene is strongly reduced (Klee, 1993). In 'Pedro Sato' guavas, such high dependence on ethylene to produce lycopene was not evident.

Summarizing, the 'Pedro Sato' guava presents a gradual increase in both respiratory rate and ethylene production after harvest and completes its ripening with changes in quality attributes. Ethylene was necessary for the skin colour development and firmness loss during ripening. These characteristics would classify this guava as a climacteric fruit. However, maximum respiratory activity, as well as the maximum ethylene production, was observed when the fruits were already ripe. In addition, the exogenous application of ethylene had no effect on the ripening process. Such evidence is contrary to the classification of 'Pedro Sato' guava as a traditional climacteric fruit. Our results show that the climacteric and non-climacteric classification is rather general and fails to take into account the peculiarities of each species.

Acknowledgements: The authors are grateful to the Conselho Nacional de Desenvolvimento Científico e Tecnológico CNPq (M. Azzolini, A.P. Jacomino and R.A. Kluge) and to the Coordenadoria de Aperfeiçoamento de Pessoal de Nível Superior - CAPES (I.U. Bron) for the fellowships granted. The authors also thank Dr. Walter Pereira, AgroFresh Inc. for providing the SmartFresh ${ }^{\mathrm{TM}}$ and Val Frutas for providing the fruits.

\section{REFERENCES}

Akamine EK, Goo T (1979) Respiration and ethylene production in fruits of species and cultivars of Psidium and species of Eugenia. J. Am. Soc. Hortc. Sci. 104:632-635.

Atta-Aly MA, Brecht JK, Huber DJ (2000) Ethylene feedback mechanisms in tomato and strawberry fruit tissues in relation to fruit ripening and climacteric patterns. Postharvest Biol. Technol. 20:151-162.

Biale JB (1964) Growth, maturation and senescence in fruits. Science. 146: 880-888.

Biale JB, Barcus DE (1970) Respiratory patterns in tropical fruits of the Amazon basin. Trop. Science. 12:93-104.

Biale JB, Young RE (1981) Respiration and ripening in fruits retrospect and prospect. In: Friend J, Rhodes MJ (eds), Recent Advances in the Biochemistry of Fruits and Vegetables, pp.1-40. Academic Press, New York, USA.

Blankenship SM, Dole JM (2003) 1-Methylcyclopropene: a review. Postharvest Biol. Technol. 28:1-25.

Bleinroth EW (1996) Colheita e beneficiamento. In: Gorgatti NA, Garcia AE, Ardito EFG, Garcia EEC, Bleinroth EW, Matalio M, Chitarra MIF, Borin MR (eds), Goiaba para Exportação: Procedimentos de Colheita e Pós-Colheita, pp.12-23. EMBRAPA, Brasília. (Série Publicações Técnicas FRUPEX, 20).

Botelho RV (1996) Efeito do tratamento pós-colheita com cálcio na ocorrência de antracnose (Colletotrichum gloeosporioides Penz) e no amadurecimento de goiabas (Psidium guajava L.) Branca de Kumagai. Botucatu, Universidade Estadual Paulista, MSc Thesis.

Bron IU, Ribeiro RV, Cavalini FC, Jacomino AP, Trevisan MJ (2005) Temperature related changes in respiration and $Q_{10}$ coefficient of guava fruit. Sci. Agricola. 62:458-463. 
Brown BI, Wills RBH (1983) Post-harvest changes in guava fruit of different maturity. Sci. Hortic. 19:23-243.

Bufler G (1986) Ethylene-promoted conversion of 1aminocyclopropane-1-carboxylic acid to ethylene in apple at various stages of fruit development. Plant Physiol. 80: 539-543.

Chitarra MI, Chitarra AB (1990) Pós-colheita de frutos e hortaliças: fisiologia e manuseio. ESAL/FAEPE, Lavras.

Cross J (1987) Pigments in fruits. Academic Press, London, UK.

El-Zoghibi M (1994) Biochemical changes in some tropical fruits during ripening. Food Chem. 59:395-399.

Gerasopoulos D, Richardson DG (1996) Effects of exogenous propylene and fruit calcium on ripening of non-chilled and chilled Anjou pears. Postharvest Biol. Technol. 8:111-120.

Giovannoni J (2001) Molecular biology of fruit maturation and ripening. Annu. Rev. Plant Physiol. 52:725-749.

Golding JB, Shearer D, Wyllie SG, McGlasson, WB (1998) Application of 1-MCP and propylene to identify ethylene-dependent ripening processes in mature banana fruit. Postharvest Biol. Technol. 14:87-98.

Hoffman NE, Yang SF (1980) Changes in L-aminocyclopropane-L-carboxylic acid content in ripening fruits in relation to their ethylene production rates. J. Am. Soc. Hort. Sci. 105:492-495.

Klee HJ (1993) Ripening physiology of fruit from transgenic tomato (Lycopersicon esculentum) plants with reduced ethylene synthesis. Physiol. Plant: 102:911-916.

Knee M, Sargent JA, Osborne DJ (1977) Cell wall metabolism in developing strawberry fruit. J. Exp. Bot. 28:377-396.

Lelièvre JM, Latché A, Jones B, Bouzayen M, Pech JC (1997) Ethylene and fruit ripening. Physiol. Plant. 101:727-739.

Ludford PM (2003) Hormonal changes during postharvest. In: Bartz JA, Brecht JK (eds), Postharvest Physiology and Pathology of Vegetables, pp.31-78. Marcel Dekker, New York, USA.

Mattiuz B (2002) Fisiologia e qualidade pós-colheita de goiabas. Jaboticabal, Universidade Estadual Paulista. PhD Thesis.

McMurchie EJ, McGlasson WB, Eaks IL (1972) Treatment of fruit with propylene gives information about the biogenesis of ethylene. Nature. 237:235-236.
Medina JC, Castro JV, Sigrist JMM, de Martin ZJ, Kato K, Maia ML, Garcia AEB, Fernandes RSS (1988) Goiaba: cultura, matéria-prima, processamento e aspectos econômicos. $2^{\text {nd }}$ ed. Campinas, Instituto de Tecnologia de Alimentos, Série Frutas Tropicais 6.

Mercado-Silva E, Bautista PB, Garcia-Velasco MA (1998) Fruit development, harvest index ripening changes of guavas produced in central Mexico. Postharvest Biol. Technol. 13:143-150.

Oetiker JH, Yang SF (1995) The role of ethylene in fruit ripening. Acta Hortic. 398:167-178.

Oliveira MA, Cereda MP (1999) Efeito da película de mandioca na conservação de goiabas. Braz. J. Food Technol. 12: 97-102.

Reyes MU, Paull RE (1995) Effect of storage temperature and ethylene treatment on guava (Psidium guajava L.) fruit ripening. Postharvest Biol. Technol. 6:365-370.

Rhodes MJC (1980) The maturation and ripening of fruits. In: Thimann KV, Delman RC, Roth GS (eds), Senescence in Plants, pp.157-205. CRC Press, Florida, USA.

Romani RJ (1984) Respiration, ethylene, senescence, and homeostasis in an integrated view of postharvest life. Canad. J. Bot. 62:2950-2955.

Sharma S, Rajat K, Prasad R, Vasuderian P (1999). Biology and potencial of Psidium guajava. J. Scient. Ind. Research. 58:414-421.

Sisler EC, Serek M (1997) Inhibitors of ethylene responses in plants at the receptor level: recent developments. Physiol. Plant. 100:577-582.

Watada AE, Herner RC, Kader AA, Romani RJ, Staby GL (1984) Terminology for the description of developmental stages of horticultural crops. HortScience. 19:20-21.

Wills R, McGlasson B, Graham D, Joyce D (1998) Introducción a la fisiología y manipulación poscosecha de frutas, hortalizas y plantas ornamentales. $2^{\text {th }}$ edn. Acribia, Zaragoza.

Yang SF (1985) Biosynthesis and action of ethylene. HortScience. 20:41-45.

Yen HC, Lee S, Tanksley SD, Lanahan MB, Klee HJ, Giovannoni JJ (1995) The tomato never-ripe locus regulates ethylene inducible gene expression and is linked to a homolog of the Arabidopsis ETR1 gene. Plant Physiol. 107:1343-1353. 